\title{
The Taxonomy of the Brown Rot Fungi (Monilinia spp.) Related to their Extracellular Cell Wall-degrading Enzymes
}

\author{
By H. J. WILLETTS,* R. J. W. BYRDE AND A. H. FIELDING \\ Long Ashton Research Station, University of Bristol, Bristol BS $189 A$ \\ AND A.-L. WONG† \\ School of Botany, University of New South Wales, Australia
}

(Received 2 May 1977)

\begin{abstract}
Patterns of extracellular enzymes secreted by the brown rot fungi Monilinia fructigena, $M$. fructicola, $M$. laxa and $M$. laxa f. sp. mali were studied by column isoelectric focusing. Of the four enzymes assayed, $\alpha$-L-arabinofuranosidase (AF) showed the greatest differences between species. Thus $M$. fructicola had high AF activity at isoelectric point (pI) $5 \cdot \mathrm{I}$, $M$. fructigena had AF peaks at $\mathrm{pI} 3 \cdot 0$ and $7 \cdot 0, M$. laxa showed activity over the pI range $6 \cdot 0$ to about $7 \cdot 3$ with distinct peaks at $6 \cdot 7$ and $7 \cdot 2$, and $M$. laxa f. sp. mali had very high AF activity at $\mathrm{pI} 7 \cdot 2$. The pectinlyase (PL) patterns were also useful for identification: the characteristic molecular form of PL in cultures of $M$. laxa and $M$. laxa f. sp. mali was at pI 9.I, while the two other species showed single peaks of activity at about pI 8.5. However, some $M$. laxa isolates also produced a peak at $\mathrm{pI} 8.5$, although this was less active than the characteristic one at $\mathrm{pI} 9 \cdot \mathrm{I}$. The polygalacturonase and pectinesterase enzyme patterns were not useful for distinguishing between the Monilinia fungi. The AF and PL enzyme patterns from known isolates were used to identify several 'unknown' brown rot cultures, including $M$. laxa isolates from stone fruits in Australia and M. laxa from Stranvaesia undulata, a new host in England.
\end{abstract}

\section{INTRODUCTION}

The usual criteria for identifying the brown rot fungi [Monilinia (=Sclerotinia) spp.] of pears, apples and stone-fruits include spore colour, type of conidial pustules produced on infected fruits, mode of branching of germ tubes arising from conidia, cultural characteristics, and host and tissue specificities (Wormald, I954). When using these criteria to identify an isolate, it is often necessary to compare unknown with known cultures. This may be inconvenient and also dangerous, as exotic cultures must be collected and new pathogens may be introduced. Furthermore, the characters vary even within species and are, therefore, not always satisfactory for accurate identification.

In the pathogenicity of these fungi, extracellular enzymes that degrade host cell walls play an important role (Byrde \& Willetts, 1977). This investigation was aimed to determine whether patterns of these enzymes, obtained by the use of column isoelectric focusing, could distinguish between brown rot fungi.

* Permanent address: School of Botany, University of New South Wales, Kensington, 2033, Australia.

$\dagger$ Permanent address: Department of Agriculture, New Town, Tasmania, 7008, Australia. 
Table I. Details of isolates of Monilinia spp.

\begin{tabular}{|c|c|c|c|c|}
\hline Reference code & Host & $\begin{array}{l}\text { Country } \\
\text { of origin }\end{array}$ & $\begin{array}{l}\text { Date of } \\
\text { isolation }\end{array}$ & $\begin{array}{l}\text { Species name } \\
\text { given, based on } \\
\text { general criteria }\end{array}$ \\
\hline \multicolumn{5}{|c|}{ Isolates used as standards } \\
\hline $\mathbf{L I}$ & Peach fruit & France & 1974) & \multirow{6}{*}{ M. laxa } \\
\hline L2 & Peach fruit & England & 1974 & \\
\hline L3 & Peach fruit & Italy & 1974 & \\
\hline $\mathbf{L} 4$ & Apricot fruit & Turkey & 1962 & \\
\hline L5 & Plum twig & England & I975 & \\
\hline 26 & Nectarine fruit & England & -1 & \\
\hline $\operatorname{LmI}(\mathrm{CBS} 290.3 \mathrm{I})$ & Apple twig & Netherlands & - & \multirow[t]{4}{*}{ M. laxa f. sp. mali } \\
\hline FCI & Peach fruit & Australia & 1965) & \\
\hline $\mathbf{F C 2}$ & $\begin{array}{l}\text { Single ascospore } \\
\text { isolate - from } \\
\text { apothecium on } \\
\text { peach mummy }\end{array}$ & Australia & 1974 & \\
\hline $\mathrm{Fc}_{3}$ & Apricot fruit & Australia & 1972) & \\
\hline $\begin{array}{l}\text { F1 (ATCC26IO6) } \\
\text { F2 (Herb. IMII62408) }\end{array}$ & $\begin{array}{l}\text { Apple fruit } \\
\text { Malus pumila }\end{array}$ & $\begin{array}{l}\text { England } \\
\text { England }\end{array}$ & $\left.\begin{array}{l}1969 \\
1971\end{array}\right\}$ & M. fructigena \\
\hline \multicolumn{5}{|l|}{ Unidentified cultures } \\
\hline $\mathrm{x}_{1}(75 / 63)$ & Flowering quince & $\begin{array}{l}\text { N.S.W., } \\
\text { Australia }\end{array}$ & 1975 & \\
\hline$x_{2}(74 / 175)$ & Flowering quince & $\begin{array}{l}\text { Victoria, } \\
\text { Australia }\end{array}$ & I974 & \\
\hline$x_{3}(75 / 23)$ & Flowering cherry & $\begin{array}{l}\text { N.S.W., } \\
\text { Australia }\end{array}$ & I975 & \\
\hline$X_{4}\left(74 / I 59^{A}\right)$ & Cherry & $\begin{array}{l}\text { Victoria, } \\
\text { Australia }\end{array}$ & I974 & \\
\hline UI & $\begin{array}{c}\text { Stranvaesia } \\
\text { undulata }\end{array}$ & England & I975 & \\
\hline
\end{tabular}

\section{METHODS}

Details of the isolates used are given in Table I. Isolates of the three common brown rot species, M. fructigena (Aderh. \& Ruhl.) Honey, M. laxa (Aderh. \& Ruhl.) Honey and M. fructicola (Wint.) Honey were obtained from Europe and Australia. Only one culture of $M$. laxa f. sp. mali (Wormald) Harrison was available.

During the investigation $M$. laxa was reported to be infecting ornamental quince, cherry plum and commercial peaches and plums at the flowering stage in the Orange district of New South Wales, Australia, where the fungus was previously unknown. To test the extracellular cell wall-degrading enzyme patterns as taxonomic criteria, we assayed isolates of the new brown rot pathogen from New South Wales and cultures from Victoria, where $M$. laxa had previously been reported (Jenkins, 1965). A brown rot fungus isolated from twigs of Stranvaesia undulata growing in England was also tested.

Cultures were grown for II days in ammonium tartrate/sodium polypectate liquid medium (Byrde \& Fielding, 1968) before the mycelia were filtered off and the filtrates were dialysed against distilled water for 24 to $48 \mathrm{~h}$ at $4{ }^{\circ} \mathrm{C}$ and then freeze-dried. As a quarantine precaution, filtrates of the Australian cultures were passed through a Millipore filter to remove mycelial and other fungal fragments before lyophilization and sealing in small glass ampoules. This treatment did not change the pectolytic enzyme patterns. The culture filtrates were electrofocused on an LKB I10 ml column (Laborda, Fielding \& Byrde, 1973) for 3 days. Elution was controlled by a peristaltic pump and the eluted fractions were assayed for the extracellular enzymes, pectinesterase [PE; pectin pectyl-hydrolase, EC 3.I.I.II], pectinlyase [PL; poly(methoxygalacturonide) lyase, EC 4.2.2 . I0; formerly pectin methyl-trans-eliminase], polygalacturonase [PG; poly $(\mathrm{I}, 4-\alpha-\mathrm{D}-$ galacturonide) glycanohydrolase, EC 3.2.I.I5] and $\alpha$-L-arabinofuranosidase [AF; $\alpha$-L-arabinofuranoside arabinohydrolase, EC 3.2.1.55].

Estimation of enzyme activities. PL, PG and AF were assayed by the methods described by Byrde \& Fielding (1968). PE was estimated by back-titration with $0.0 \mathrm{I} \mathrm{M}-\mathrm{NaOH}$ to $\mathrm{pH} 5.0$ at $25^{\circ} \mathrm{C}$, using a substrate mixture of $0.5 \%(\mathrm{w} / \mathrm{v})$ pectin (Brown Ribbon brand, Union Crystalex Gelatine Ltd, London) in O. I $\mathrm{M}-\mathrm{NaCl}$ containing $0.1 \%(\mathrm{w} / \mathrm{v})$ phenol, adjusted to $\mathrm{pH} 5.0$ with $\mathrm{I} \mathrm{M}-\mathrm{NaOH}(\mathrm{NaCl}$ activates $\mathrm{PE}$, and phenol prevents microbial contamination). The reaction mixture consisted of $10 \mathrm{ml}$ substrate with $\mathrm{O} \cdot \mathrm{I} \mathrm{ml}$ sample. 
Table 2. Summary of average $\mathrm{pI}$ values (in the range 3 to 10) of extracellular enzymes of isolates of the brown rot fungi

Some indication of the relative activity of each enzymic form is shown: $\equiv$, very high; $=$, high; - moderate; no underline, low activity. Numbers in parentheses indicate that the form of the enzyme at that $\mathrm{pI}$ was detected only occasionally and, when observed, the activity was low.

Species

\begin{tabular}{|c|c|c|c|c|c|c|c|c|c|c|}
\hline$\alpha-L-A r a$ & nofu & nosic & & Pecti & yase & & lygala & turon & & Pectin- \\
\hline${\underline{\underline{5 \cdot 1^{a}}}}^{a}$ & & & $7 \cdot I$ & $8 \cdot 3^{a}$ & & & & & $9 \cdot 7^{b}$ & $5 \cdot 0^{a}$ \\
\hline & & & $7 \cdot 0$ & $8 \cdot 4$ & & $(2 \cdot 8)$ & $4 \cdot 4$ & $(5 \cdot 5)$ & $9 \cdot 7$ & $4 \cdot 8$ \\
\hline & $6 \cdot 0$ & $6 \cdot 7$ & $7 \cdot 2^{a}$ & $8 \cdot 5$ & $9 \cdot I^{a}$ & $(3.0)$ & {$\left[\left(4^{6} 6\right)\right.$} & & ${\underline{\mathbf{I O}} \cdot \mathrm{I}^{a}}^{a}$ & $4^{\cdot} 8^{a}$ \\
\hline & & & $\underline{\underline{7 \cdot 2}}$ & & $9 \cdot I$ & & & $5 \cdot I$ & $9 \cdot 7$ & $4 \cdot 7$ \\
\hline
\end{tabular}

Standard errors of mean: $a, \pm 0 \cdot \mathbf{I} ; b, \pm 0.2$.

\section{RESULTS}

\section{Standard isolates}

The isoelectric points (pI) of the AF, PL, PG and PE enzymes of isolates identified morphologically as $M$. fructicola, $M$. fructigena, $M$. laxa and $M$. laxa f. sp. mali are shown in Table 2. The enzymic forms of the isolates of any one species had very consistent pI values but they differed in absolute activity. Isolates of different species often differed greatly. Patterns of the AF, PL and PG enzymes for typical isolates of the four brown rot fungi are illustrated in Fig. I. The heights of the peaks varied between isolates of the same species, indicating different enzyme activities, but the overall patterns were similar.

$\alpha$-L-Arabinofuranosidase. A form of the AF enzyme with a pI'about $7 \cdot$ I was common to all isolates, being particularly active in filtrates of $M$. laxa f. sp. mali where it was the only form detected (Fig. I $d$ ). In $M$. laxa cultures, AF activity was detected between pI $6 \cdot 0$ and $7 \cdot 2$ (Fig. I $c$ ) with little activity at the bottom of the range but with two distinguishable peaks at $6 \cdot 7$ and $7 \cdot 2$. Cultures of $M$. fructicola and $M$. fructigena had a pattern different from the above, but the heights of the three peaks differed between the two species (Fig. I $a, b$ ); in the former there was high activity at pI $5 . \mathrm{I}$ with low peaks at 3.0 and $7 . \mathrm{I}$, while in cultures of $M$. fructigena there was only occasional low activity at pI $5^{\circ} 0$ compared with the distinct peaks at $\mathrm{pI} 3 \cdot 0$ and $7 \cdot \mathrm{I}$.

Pectinlyase. There was a common, active form of the PLenzyme at pI 8.2 to 8.5 in $M$. fructicola, $M$. fructigena and $M$. laxa (Fig. I $e, f, g$ ) but $M$. laxa had an additional more active enzymic form at $\mathrm{pI} 9 \cdot \mathrm{I}$. Monilinia laxa $\mathrm{f}$. sp. mali (Fig. I $h$ ) had only one detectable enzymic form at $\mathrm{pI} 9 \cdot \mathrm{I}$.

Polygalacturonase. The characteristic feature of the PG patterns of all isolates was the common peak at $\mathrm{pI} 9.7$ to $10 . \mathrm{I}$. This was substantially the only peak detected in PG patterns from $M$. fructicola cultures (Fig. $\mathrm{I} i$ ) and was very high. In $M$. fructigena cultures (Fig. $\mathrm{I} j$ ), apart from the moderately active, common peak at pI 9.7, three forms of the PG enzyme with low activity were sometimes detected at pI values of about $2 \cdot 8,4.4$ and 5.5 , with a shoulder at $\mathrm{pI}$ 8. The PG pattern for $M$. laxa isolates (Fig. $\mathrm{I} k$ ) was similar to that of $M$. fructigena with low activities at $\mathrm{pI} 3.0$ and 4.6 and a moderately active peak at about $\mathrm{rO} \cdot \mathrm{I}$. The PG enzyme pattern for $M$. laxa f. sp. mali (Fig. I $l$ ) had two peaks, a large one at pI $5 \cdot \mathrm{I}$, and a moderate one at $\mathrm{pI} 9 \cdot 7$.

Pectinesterase. Only one form of the PE enzyme with pI about 4.8 was detected. It was common to all the brown rot cultures studied. 


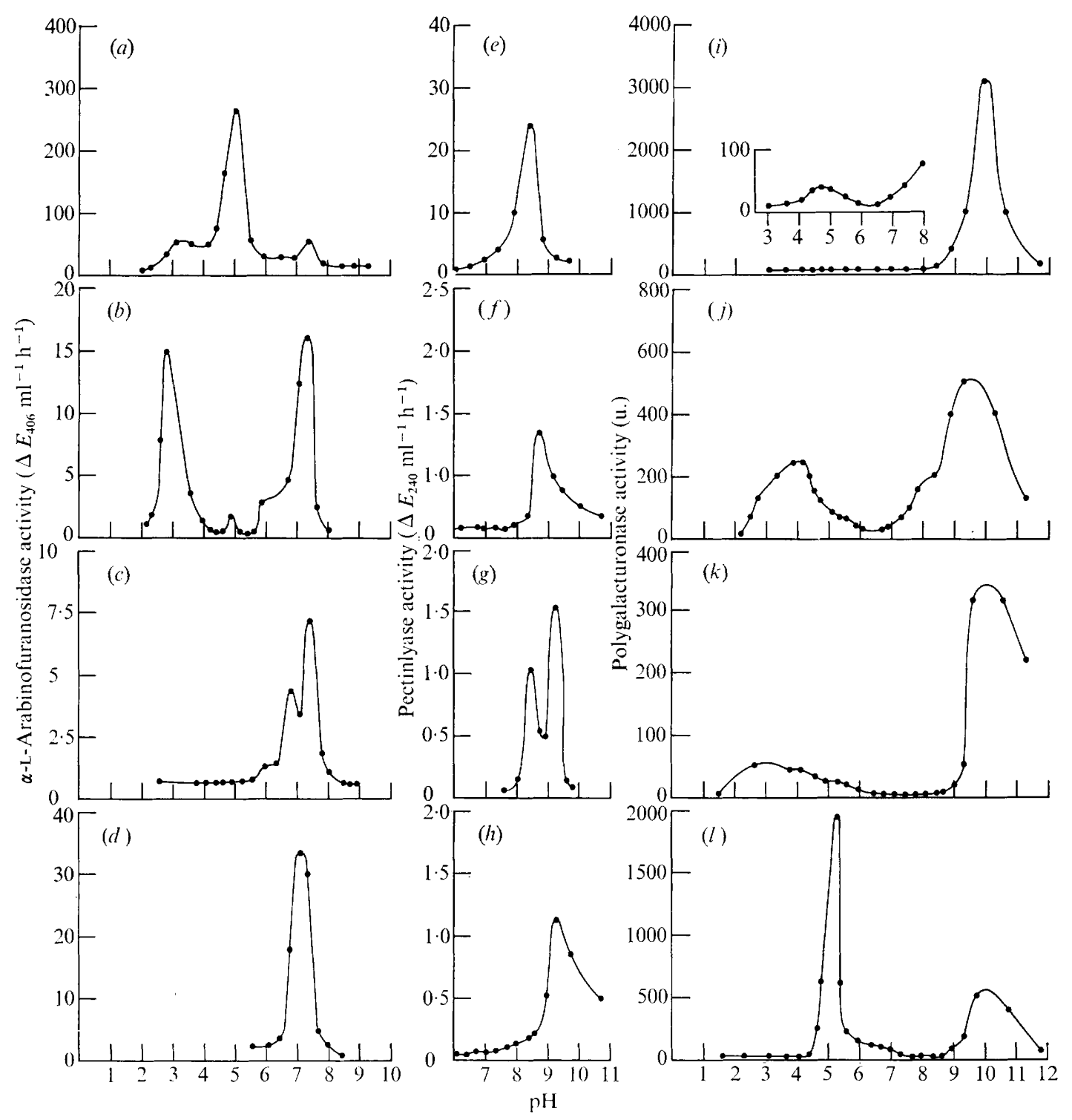

Fig. I. Cell wall-degrading enzyme patterns obtained by isoelectric focusing of filtrates from cultures of selected brown rot fungi. $(a-d) \alpha$-L-Arabinofuranosidase; $(e-h)$ pectinlyase; $(i-l)$ polygalacturonase; inset in (i) shows PG activity over pI range 3 to 8 with the activity scale expanded Io-fold. ( $a, e, i)$ Monilinia fructicola $(\mathrm{FcI}) ;(b, f, j) M$. fructigena $(\mathrm{F} 2) ;(c, g, k) M$. laxa $(\mathrm{LI}) ;(d, h, l)$ M. laxa f. sp. mali (LmI).

\section{Unidentified isolates}

Patterns for AF and PL enzymes for four of the five unidentified isolates are shown in Fig. $2(a-h)$. The excluded isolate $\left(\mathrm{x}_{2}\right)$ gave results very similar to those of isolate $\mathrm{x}_{1}$ (Fig. $2 b, f)$. Patterns for PG showed no characteristics that could be used to distinguish between these cultures.

The AF and PL enzyme patterns of isolate $\mathrm{x}_{4}$ (Fig. $2 a, e$ ) were very similar to those of M. fructicola (Fig. I $a, e$ ). Isolates $\mathrm{x}_{1}$ (Fig. $2 b, f$ ), $\mathrm{x}_{2}$ and $\mathrm{x}_{3}$ (Fig. $2 c, g$ ) had AF patterns characteristic of the standard $M$. laxa cultures; also all the PL patterns (Fig. $2 f, g$ ) had peaks at pI 9.I, comparable with those detected in the standard $M$. laxa and $M$. laxa f. sp. mali 

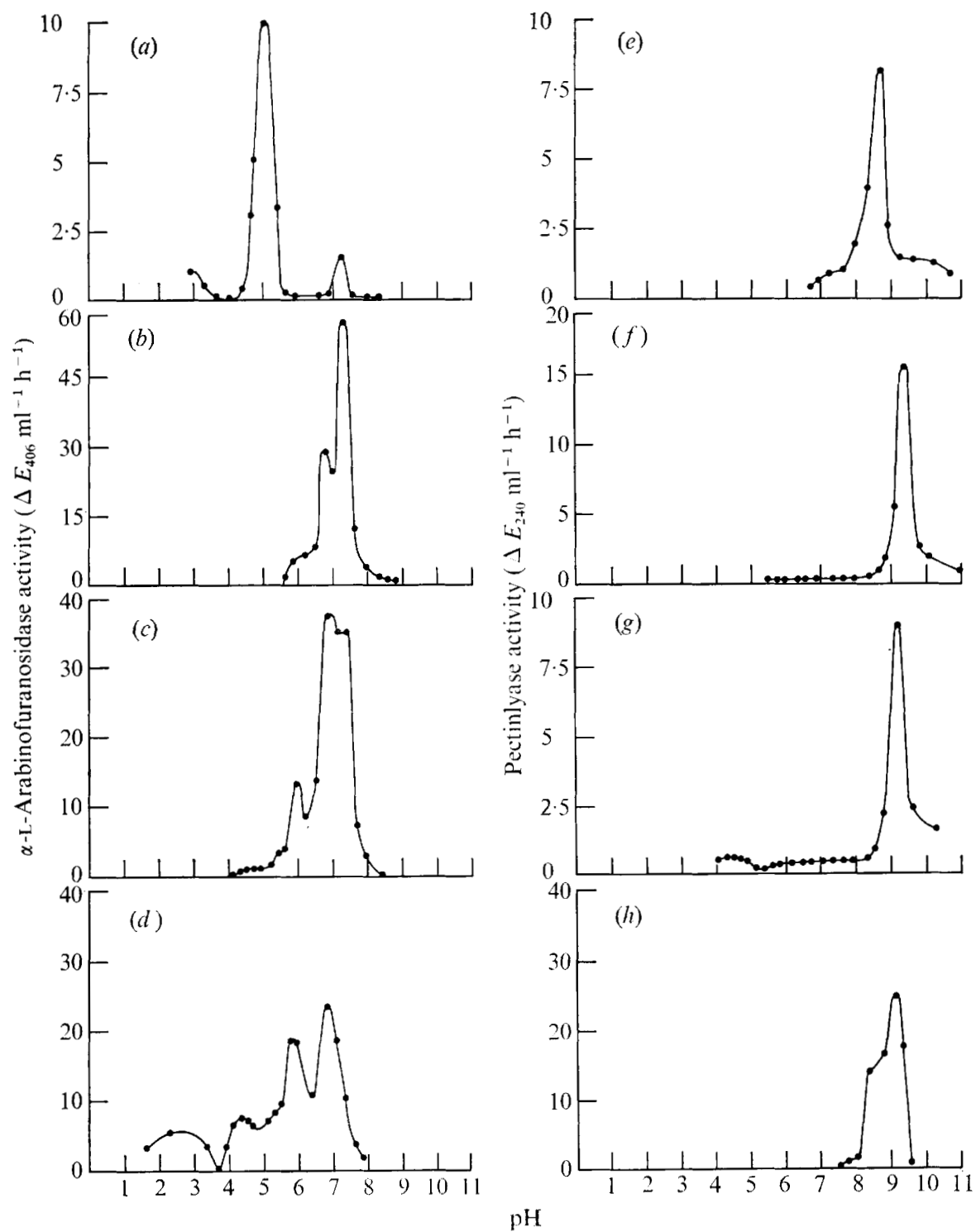

Fig. 2. Cell wall-degrading enzyme patterns obtained by isoelectric focusing of filtrates from cultures of selected brown rot fungi. $(a-d) \alpha$-L-Arabinofuranosidase; $(e-h)$ pectinlyase. $(a, e)$ Isolate $\mathrm{X}_{4} ;(b, f)$ isolate $\mathrm{x}_{1} ;(c, g)$ isolate $\mathrm{X}_{3} ;(d, h)$ isolate UI.

cultures, but had no activity at $\mathrm{pI} 8 \cdot 5$, unlike the patterns obtained from the standard $M$. laxa cultures.

Isolate UI had an AF pattern (Fig. $2 d$ ) similar to that of $M$. laxa, with moderate activity over a pI range of $6 \cdot 0(5 \cdot 6)$ to $7 \cdot \mathrm{I}$, but with two additional small peaks with $\mathrm{pI}$ values of about 3.0 and 4.4 . The PL pattern for UI (Fig. $2 h$ ) had the characteristic $M$. laxa peak at pI 9.I with a shoulder at about $8 \cdot 3$.

\section{DISCUSSION}

The investigation suggests that there are consistent differences in AF and PL patterns that could help in distinguishing between species of the brown rot fungi. Confirmation is needed 
that the enzymes at the same isoelectric points are indeed the same. This might be achieved by immunoelectrophoresis and determination of molecular weights.

The AF patterns were the best for identifying the brown rot fungi. Thus, $M$. fructicola was distinguished by high activity at $\mathrm{pI} 5 \cdot \mathrm{I}, M$. fructigena had maximum activity at 3.0 and 7.0 (cf. Laborda et al., I973), $M$. laxa showed activity over a wide range of pI values but with most from pI $6 \cdot 0$ to about $7 \cdot 3$, and $M$. laxa f. sp. mali had very high activity at $7 \cdot 2$.

The PL patterns were useful for distinguishing $M$. laxa and its forma specialis from $M$. fructicola and $M$. fructigena. The two last fungi had one form of the PL enzyme of $\mathrm{pI} 8 \cdot 2$ to $8 \cdot 5$. Although the standard $M$. laxa isolates had one enzymic form at pI $8 \cdot 5$, a second, more active form occurred at $\mathrm{pI} 9 \cdot \mathrm{I}$ and this was the only one detected in $M$. laxa f. sp. mali filtrates. The later studies on initially unidentified material indicate that the main PL enzymic form in $M$. laxa cultures has a pI of 9.1 and the form at 8.5 is not always active.

The PG enzyme patterns were less useful for identification; the very high peak at $5 \cdot \mathrm{I}$ for $M$. laxa f. sp. mali may help to distinguish this fungus from other members of the group, but more isolates need to be studied.

The PE enzyme patterns had no taxonomic value.

Comparing the AF and PL patterns of the four 'unknown' brown rot cultures from Australia with standard isolates of $M$. laxa and $M$. fructigena from Europe, and $M$. fructicola from Australia, indicated that three were $M$. laxa and one was $M$. fructicola. These results support the conclusions of Penrose, Tarran \& Wong (1976) on morphological and electrophoretic evidence, that $M$. laxa is now established on growing crops in New South Wales, Australia. Our findings also support Jenkins' (1965) report that $M$. laxa is a pathogen of stone fruits in Victoria, Australia. The fungus isolated in England from Stranvaesia undulata, a host on which Monilinia spp. had not been recorded before, was characteristic of $M$. laxa although the AF pattern showed activity over a wider range of $\mathrm{pI}$ than observed in other M. laxa isolates.

Although the enzyme patterns differ characteristically between species, a basic pattern for the genus is discernible in the PE, AF and PG enzymes. Perhaps the ancestor(s) from which the brown rot fungi evolved had simple enzyme patterns, and subsequent changes in them would be related to adaptation of variant forms of the fungus to particular hosts and/or habitats. From some of the records of the establishment of brown rot species in new areas (Barss, I923; Jenkins, 1965; Boesewinkel \& Corbin, 1970; Penrose et al., 1976) it seems that $M$. laxa adapts more readily to different environmental conditions than either $M$. fructigena or $M$. fructicola. The $M$. laxa isolates showed activity over wider $\mathrm{pI}$ ranges for both AF and PL enzymes, and possibly this applies to other enzymes not included in the investigation. This could confer on the species a greater enzymic plasticity than is found in the other two species. However, activity was not detected at low $\mathrm{pI}$ values. The least number of enzymic forms were observed in cultures of $M$. laxa $\mathrm{f}$. sp. mali, and this could be related to the narrow host and tissue specificities and restricted regional distribution of the fungus. Probably the relationships between enzyme forms with varying host and tissue specificities could be determined from detailed studies on a range of fungal material collected from selected areas.

The association between the brown rot species and their hosts is thought to have originated in the Far East with secondary centres in the Transcaucasian region of the Middle East and in North America (Byrde \& Willetts, 1977). Studies on enzyme patterns of isolates of the brown rot fungi from these regions could help explain the evolutionary affinities of Monilinia spp. Of particular interest would be the patterns obtained from cultures of Monilinia mali (Tak.) Whetzel and several of the other interesting brown rot fungi reported from Japan (Wormald, 1954).

It is concluded that AF and PL enzyme patterns are useful for confirming morphological identifications of the brown rot fungi. Further studies with isoelectric focusing and 
complementary techniques, such as immunoelectrophoresis, could help explain the intraand inter-specific relationships within this and other groups of fungi.

We thank Professor J. M. Hirst, F.R.S., and Dr R. S. Vickery for critical reading of the manuscript, Mrs Sue Lowry for help with the figures, and Mr J. B. Sweet for supplying the infected specimens of Stranvaesia undulata. Financial support was obtained during the investigation from the United Kingdom Agricultural Research Council and the Rural Credits Development Fund of the Reserve Bank of Australia. H.J.W. wishes to acknowledge a travel grant from the British Council during the time he was on study leave in Britain.

\section{REFERENCES}

BARss, H. P. (1923). Brown rot and related diseases of stone fruits in Oregon. Circular of the Oregon Agricultural Experiment Station 53.

Boesewinkel, H. J. \& Corbin, J. B. (1970). A new record of brown rot Sclerotinia (Monilinia) laxa in New Zealand. Plant Disease Reporter 54, 504506.

Byrde, R. J. W. \& Fielding, A. H. (1968). Pectin methyl-trans-eliminase as the maceration factor of Sclerotinia fructigena and its significance in brown rot of apple. Journal of General Microbiology 52, 287-297.

Byrde, R. J. W. \& Willetts, H. J. (1977). The Brown Rot Fungi of Fruits: Their Biology and Control. Oxford: Pergamon Press.

Jenkins, P. T. (I965). Sclerotinia laxa Aderh. \&
Ruhl.: a cause of brown rot of stone fruits not previously recorded in Australia. Australian Journal of Agricultural Research 16, I4 I-I44.

Laborda, F., Fielding, A. H. \& Byrde, R. J. W. (I973). Extra- and intra-cellular $\alpha$-L-arabinofuranosidase of Sclerotinia fructigena. Journal of General Microbiology 79, 321-329.

Penrose, L. J., Tarran, J. \& Wong, A.-L. (1976). First record of Sclerotinia laxa Aderh. \& Ruhl. in New South Wales: differentiation from $S$. fructicola (Wint.) Rehm by cultural characteristics and electrophoresis. Australian Journal of Agricultural Research 27, 547-556.

WORMALD, H. (1954). The brown rot diseases of fruit trees. Ministry of Agriculture, Fisheries and Food, Technical Bulletin No. 3. London: H.M.S.O. 